\title{
TRTaKadeмi
}

ISSN 2149-9446 | Cilt 07 | Sayı 14 | Ocak 2022 | Sosyal Medya

\section{Sporcuların Perspektifinden Sosyal Medyada Siber Zorbalık}

\author{
Cem YÜCETÜRK* - Besna AĞIN**
}

\begin{abstract}
Öz
İçinde bulunduğumuz çağın en önemli sorunlarından biri, dijital teknolojiler ve sosyal medya aracılığı ile insanlara zarar vermeyi amaçlayan siber zorbalık olarak adlandırılan davranışlardır. Siber zorbalık, fiziksel ortamda gerçekleştirilen zorbalıklardan farklı özellikler taşır. Gençlerin yeni medya okuryazarlığı becerisinden mahrum şekilde sosyal medya kullanması, siber zorbalığın yaygın bir sorun hâline gelmesine neden olmaktadır. Siber zorbalık içeren eylemlere en fazla maruz kalan gruplardan birisi de sporculardır. Sporcular cinsiyetleri, ırkları, fiziksel özellikleri, performansları vb. sebeplerle birçok saldırıyla baş etmek durumunda kalmaktadırlar. Çalışmada konunun önemine dikkat çekmek için dünyada ve ülkemizde sporcuların karşı karşıya kaldığı siber zorbalıklara ve bu zorbalıkların sporcuların hayatlarını nasıl etkilediğine dair örneklere yer verilmiştir. Bu çalışmanın amacı özellikle siber zorbalıklardan daha fazla etkilenme intimalleri olan genç sporcuların perspektifinden konuya yaklaşarak, siber zorbalık hakkında farkındalık seviyelerini tespit etmektir. Bu amaç doğrultusunda çalışmada 18-25 yaş arasında çeşitli branşlarda spor yapan 15 genç sporcu ile derinlemesine görüşmeler yapılmıştir. Sonrasında ise çeşitli temalar oluşturularak görüşmelerden elde edilen veriler analiz edilmiştir.
\end{abstract}

Anahtar Kelimeler: Siber Zorbalık, Spor, Sosyal Medya, Dijital Teknolojiler, Sporcular

*Öğr. Gör., Amasya Üniversitesi Sosyal Bilimler Meslek Yüksekokulu Pazarlama ve Reklamcılık Bölümü, cem.yuceturk@amasya.edu.tr

**Arş. Gör., Üsküdar Üniversitesi Illetişim Fakültesi Radyo, Televizyon ve Sinema Bölümü, besna.agin@uskudar.edu.tr

Yücetürk, C. \& Ağın, B. (2022). Sporcuların Perspektifinden Sosyal Medyada Siber Zorbalık. TRT Akademi, 7 (14), 154-181. DOI: 10.37679/trta.1011848

\section{Araştırma Makalesi}

Geliş Tarihi: 19.10.2021

Revizyon Tarihi: 07.12.2021

Kabul Tarihi: 14.01.2022

ORCID ID: 0000-0001-6641-8790 ORCID ID: 0000-0002-1591-0352 DOI: 10.37679/trta.1011848 


\title{
TRTakadeмi
}

ISSN 2149-9446 | Volume 07 | Issue 14 | January 2022 | Social Media

\section{Cyberbullying in Social Media from Athletes' Perspective}

\author{
Cem YÜCETÜRK \\ Besna AĞıN
}

\begin{abstract}
One of the most important problems of the age we live in is cyberbullying, which aims to harm people through digital technologies and social media. Cyberbullying is different from the type of bullying carried out in the physical environment. The use of social media by young people who lack new media literacy skills causes Cyberbullying to become a widespread problem. Athletes are one of the groups most exposed to acts of cyberbullying. Athletes have to cope with many attacks due to their gender, race, physical characteristics, performance and similar reasons. In order to draw attention to the importance of the subject in the study, examples are given of cyber bullying faced by athletes around the world and in Turkey and how this bullying affect the lives of athletes. The aim of this study is to determine the awareness levels of the athletes about cyberbullying, by approaching the subject from the perspective of young athletes, who are more likely to be affected by cyberbullying. In line with this, in-depth interviews were conducted with 15 young athletes between the ages of 18-25 who play sports in various branches. After the data were obtained from the interviews, they were analyzed under various themes.
\end{abstract}

Keywords: Cyberbullying, Sports, Athletes, Social Media, Digital Technologies 


\section{Giriş}

Geleneksel zorbalığın özellikle gençler üzerindeki olumsuz etkileri literatürde yapılan birçok bilimsel çalışma ile vurgulanmaktadır. Gençlerin okul hayatlarında ve sosyal çevrelerinde yaşadıkları zorbalıkların kendilerine olan güvenlerini yitirmelerine, sağlıklı karar almalarını engellemeye ve sonuç olarak yaşadıkları sosyal ortamlardan uzaklaşmalarına neden olduğu söylenebilir. Okul çağındaki gençler bu zorbalıklarla genellikle bireysel olarak mücadele etmeye çalışmaktadır. Bu noktada spor olgusu zorbalığın bahsi geçen bu olumsuz yansımaları ile mücadele etmek açısından gençlere gereken desteği sağlayabilmekte ve bu anlamda çok önemli bir yer tutmaktadır. Sosyal çevresinde daha çekingen, içe kapanık bireyler herhangi bir sportif faaliyetle birlikte özgüven kazanarak kendisini fiziksel çevresine kabul ettirebilir. Dolayısıyla özellikle okullarda spor, yalnızca performansa yönelik olarak yarışma duygusunun ön plana çıkarılması için planlanmamaktadır. Gençlerin bu faaliyetlerin içinde olmaları, spor dışı alanlarda da yaşantılarına katkı sunabilmektedir (Pehlivan ve Konukman, 2004, s. 52). Bazı çalışmalar özellikle takım sporlarıyla uğraşmanın gençlerin zihinsel olarak sağlıklı kalmalarını, benlik saygısı kazanmalarını, yaşam keyfi ve duygusal öz-yeterlik seviyelerinin artmasını sağladığını öne sürmektedir. Bunların yanı sıra gençlerin karşı karşıya kaldıkları sosyal izolasyon, depresif ruh hâli, depresyon belirtileri, umutsuzluk, intihar gibi sorunların ise azaldığı vurgulanmaktadır (Alp, 2020, s. 77).

Ancak bu durum spor hayatında başarılı olan ve profesyonelleşen gençlerin zorbalıklara maruz kalmayacağı anlamına gelmemektedir. Dünyanın her yerinde bir spor takımı içindeki bazı sporcuları dışlamak, dedikodu üretmek, sözlü ya da fiziksel olarak taciz etmek, onlara iftira atmak gibi zorbalık türleri meydana gelmektedir. Hâlihazırda geleneksel zorbalığa maruz kalan sporcuların teknolojinin gelişip dönüşmesiyle birlikte yeni bir problemi daha ortaya çıkmıştır: siber zorbalık. Yeni iletişim araçlarının toplumun sosyo-ekonomik, kültürel ve siyasi özelliklerinden bağımsız olarak herkesi dönüştürdüğü bu çağda, sporcular da yeni medya olgusuyla karşı karşıya kalmışlardır. Dijital teknolojilerin beraberinde getirdiği sosyal ve toplumsal dönüşümler sosyal bilimlerin hemen hemen her alanında yoğun bir şekilde tartışılmaktadır. Özellikle internet teknolojisinin iletişimi demokratikleştiren yapısı ve sıradan kullanıcıların WEB 2.0 ile birlikte içerik üretimine dâhil olabilmesi, içinde bulunduğumuz çağda pazarlamadan siyasete, ekonomiden hukuka kadar toplumu ilgilendiren tüm yapıları sarsmıştır. Önceden iletişimin pasif bir aktörü olan kullanıcıların WEB 2.0 dönemine girilmesi ile birlikte içerik üretimine dahil olabilmesi, toplumsal, ekonomik ve siyasal olarak birçok değişime neden olmuştur. Ancak her bireyin bir iletişim aracı hâline dönüşmesi, bilgiye ulaşması ve 
herhangi bir editoryal sürece ihtiyaç duymadan içerik üretmesi, iletişimi demokratikleştirmenin yanında, yeni sorunların da ortaya çıkışına zemin hazırlamıştır. Demokratik bir süreç olarak her bireyin bir iletişim aracı hâline dönüşmesi, bilgiye ulaşması ve bilginin üreticisi de olması zaman zaman antidemokratik bir sürece de dönüşebilmektedir. Dijitalleşme süreci; beraberinde demokrasi ile bağdaşmayan dijital uçurum, nefret söylemi, filtre balonları, yankı odaları, özel hayatın gizliliği ve güvenliği gibi birçok kavramı da beraberinde getirmiştir.

Popüler spor dallarında faaliyet gösteren ve sürekli olarak sosyal medyada göz önünde olan sporcular için maruz kaldıkları siber zorbalık eylemleri yeni zorluklarla yüzleşmelerine sebep olmuştur. Sporcuların toplumsal olaylar hakkında paylaştıkları görüşleri, cinsiyetleri ya da cinsel tercihleri, ırkları ve performanslarına yönelik maruz kaldıkları siber zorbalık eylemlerinin boyutları, yaptıkları sporun önüne geçebilmektedir. Bu olaylarla mücadele noktasında sporcuların yalnız kalmaları onların kariyerlerini de olumsuz yönde etkilemektedir. Ancak son dönemlerde federasyonlar ve oyuncu birliklerinin bu konuda ortak adımlar attkları da gözlemlenmektedir.

\section{Siber Zorbalık Kavramına Genel Bir Bakış}

Zorbalık en genel tanımıyla, kişinin bilinçli olarak başkalarına sözlü saldırı, fiziksel taciz veya manipülasyon yoluyla zarar verme davranışıdır. Siber zorbalık ise fiziksel ortamda gerçekleştirilen zorbalık türünden farklı olarak sanal ortamda iletişimin kurulmasıyla gerçekleşmektedir. "Siber zorbalık" terimi, akademik literatürde ilk olarak 2003 yılında Bill Belsey tarafindan Kanada'da siber zorbalığı ele alan bir WEB sitesinin (http://www.cyberbullying.ca/) yayınlanmasının ardından ortaya çıkmaya başlamıştır (Bauman ve Bellmore, 2015); o zamandan beri siber zorbalığı inceleyen araştırmaların sayısı katlanarak artmıştı (Betts, 2016, s. 13).

Siber zorbalık söz konusu olduğunda kesin bir tanımlama yapmak zordur ve literatürde siber zorbalığın ne olduğuna ilişkin çok az fikir birliği vardır. Tokunaga'ya göre siber zorbalık, çevrim içi zorbalık, elektronik zorbalık ve internet üzerinden yapılan tacizleri kapsayan bir "şemsiye" terimdir (Tokunaga'dan akt. Betts, 2016, s. 18). Siber zorbalığın bazı tanımları, yüz yüze zorbalığın karakteristik özellikleri olan tekrar etme, güç dengesizliği ve niyet unsurlarından hareketle yapılmıştır. Bu tanımlarda siber zorbalığın geleneksel zorbalık tanımlarından türetildiğini ve kapsamının genişletildiğini söylemek mümkündür. Bhat (2008, s. 58), siber zorbalık davranışlarının "utandırmak, tehdit etmek, incitmek veya dışlamak" için tasarlandıklarını söyler. Borgia ve Myers ise (2010, s. 29), siber zorbalığın "birisi işkence gördüğünde, tehdit edildiğinde, taciz edildiğinde, aşağılandığında, utandığında 
veya başka bir şekilde hedef alındığında" ortaya çıktığını belirtir (Borgia ve Myers'dan akt. Betts, 2016, s. 11).

Diğer tanımlar ise, siber zorbalık davranışlarının açık ve kesin doğasını vurgulamakla birlikte siber zorbalığın gerçekleşebileceği farklı medyaları da içerir. Belsey (2006), siber zorbalığı "bilgi ve iletişim teknolojilerini kullanarak bir birey ya da grup tarafindan diğerlerine zarar vermek için tasarlanan kasıtlı, tekrarlanan ve düşmanca davranış içeren zorbalık türü" olarak tanımlamaktadır. Valkenburg ve Peter (2011, s. 124-125), siber zorbalığın bir kişiyi sistematik olarak korkutmak amacıyla o kişiyi aşağılamak, utandırmak veya incitmek için internet tabanlı uygulamalar kullanıldığında ortaya çıktığını belirtmektedir (Valkenburg ve Peter'dan akt. Betts, 2016, s. 11).

Kişinin bir başkasına karşı yaptığı tüm zorbalık türlerinde temel unsurların esasen aynı olduğu söylenebilir. Bu unsurlar, daha güçlü bir insanın, aciz olarak belirlediği bir hedefe karşı tekrar tekrar gerçekleştirdiği zulüm içeren davranış ve hareketleri içermektedir. Bir davranış veya hareketin zorbalık olarak kabul edilebilmesi için kasıtlı olması, tekrarlanması ve etkili olması gerekir ve bu durumda zorba, kurbandan daha fazla güce sahip olan kişi olarak konumlanır. Fakat siber zorbalık, her zaman bu kriterleri barındırmayabilir. Dijital mecralar söz konusu olduğunda, zorbalık olarak kabul edilen davranış ve hareketleri, bizzat zorbalık için belirlenmiş olan kriterlere uydurmak zor olabilir (Englander, 2020, s. 57-69).

Dijital alanda zorbalık, okulda çocuklar arasında gerçekleşen zorbalıktan çok farklı olabilir. Insanların dijital teknolojiyi kullanırken iletişimi nasıl algıladıkları ve anladıkları konusunda da önemli farklılıklar vardır. Genellikle yalnızca kısa metin parçalarından oluşan dijital mesajlar, yüz yüze veya telefon görüşmelerinin tüm dokusundan - ses tonu, yüz ifadeleri, beden dili, duygu ve bağlamı ileten diğer ayrıntılardan - yoksundur. Bunlara ek olarak, kişilerin asla yüz yüze söylemeyecekleri şeyleri çevrim içi olarak söylemeleri oldukça kolaydır ve duygular da dijital ortamlarda farklı şekilde deneyimlenebilmektedir. İnternette birçok siber zorbalık hareketi yazılı olarak gerçekleşir. Yüz yüze bir diyalog esnasında, her ifade konuşulur konuşulmaz yok olurken dijital mecrada kullanıcılar bu ifadeleri tekrar tekrar okuyabilmektedir. Bu tekrar, büyük bir duygusal etkiye yol açabilir ve bir kullanıcının çevrim içi olarak ifade edilen bir duyguyu ne kadar yoğun deneyimlediğini değiştirebilir (Englander, 2020, s. 57-69).

Tüm bu faktörler, dijital teknolojilerin nasıl hissettiğimiz ve ne söylediğimizi çarpıtabileceği anlamına gelir. Dolayısıyla çevrim içi iletişim, yüz yüze iletişim türlerinden çok farklı olabilir. Bunlara ek olarak yalnızca çevrim içi olarak ortaya çıkan 
sosyal çatışma, taciz ve zorbalık türleri vardır. Bu da siber zorbalığın, yalnızca geleneksel anlamda zorbalığın sanal ortama taşınması demek olmadığını ve kendine ait dinamikleri olduğunu göstermektedir.

\subsection{Siber Zorbalık ve Spor ilişkisi}

Teknolojinin hayatın her alanında olduğu gibi spor söz konusu olduğunda da doğrudan etki gücü bulunmaktadır. Teknoloji sayesinde ortaya çıkan yeni ürün ve hizmetler, yeni rekorların geliştirilmesine, kuralların değişmesine, gelirlerin artmasına ve hatta yeni spor dallarının da ortaya çıkmasına neden olmaktadır. İzleyiciler açısından da spor izleme alışkanlıkları değişmektedir. Hayatımıza 2000'li yıllarda giren HD yayın format artık bir standart hâline gelmiştir. 4K teknolojisi de spor yayınlarında giderek yaygınlaşmaktadır. Bununla birlikte sanal gerçeklik gözlükleri de yayınların 360 derece izlenmesine ve sporcuların gözünden müsabakaları izlememize olanak tanıyan yenilikler sunmaktadır. Önümüzdeki yıllarda Netflix, Amazon vb. platformların büyük spor organizasyonlarını satın alma ihtimalinin de oldukça yüksek olduğu tahmin edilmektedir. Bu tarz yenilikler hem sporculara hem de izleyicilere büyük avantajlar getirmektedir. Ancak bu yeni olanaklar beraberinde yeni sorunlar da doğurmaktadır. Artık geçmişe kıyasla çok daha fazla göz önünde olan sporcuların toplumla kurduğu iletişimin boyutu genişlemiştir. Medya kullanım alışkanlıkları da bir sporcunun performansını etkileyen yeni bir unsur olarak karşımıza çıkmaktadır. Günümüzde "scout"lar (yetenek avcıları) için bir sporcunun medya ile ilişkisi o sporcunun tercih edilip edilmemesinde önemli bir unsur olarak karşımıza çıkmaktadır. Bir sporcunun geniş kitlelerle iletişim kurabilme yeteneğinin olması taraftarlarla etkileşim hâlinde olmasını sağlayabilir.

Sosyal medya yardımıyla saha içinde olduğu kadar saha dışında da sempati kazanan sporcular, kulüplerin imajına olumlu katkılar sunabilmekte ve önemli bir tanıtım aracı hâline gelebilmektedir. Bu sayede kulüpler daha fazla sponsor elde edebilir ve daha fazla ticari ürün satabilir. Dolayısıyla bu tarz sporculara sahip olmak stratejik açıdan her zaman önemlidir. Yetenekli genç sporcuların sosyal medya platformları aracılığı ile yaptıkları paylaşımlar yetenek avcıları tarafindan takip edilmektedir. Yetenek avcıları bu sayede yüz yüze etkileşimle bile elde edemeyecekleri bazı bilgileri analiz edebilmektedirler (Radicchi ve Mozzachiodi, 2016, s. 30).

Sosyal medyanın sporcuların popülaritesini arttırmada önemli bir etken olduğu söylenebilir. Ancak bu popülerlik bir taraftan sporcuların performanslarını ve sosyal yaşantılarını olumsuz da etkileyebilir. 
Sporcuların maruz kaldığı siber zorbalık vakaları gittiçe yaygınlaşmakta ve sosyal medya-sporcu ilişkisi bağlamında bir norm hâline gelmektedir. Sporcuların yaşantılarının bir parçası hâline gelen siber zorbalık vakaları giderek normalleşmektedir. Buna karşı çıkan bazı bireysel sporcular haricinde kolektif bir mücadeleye sık rastlanmamaktadır.

Sosyal medya, bireylerin duygu ve düşüncelerini dilediği gibi ifade edebilmesine ve bunu gerçek kimliklerini kullanmadan yapmalarına olanak tanır. Taraftarların eğlenme ve rahatlama gibi birtakım duygusal ihtiyaçlarını tatmin etmek için maçları izledikleri düşünüldüğünde, ahlaki ve toplumsal engellerden dolayı fiziksel dünyada bu duygularını tam olarak karşılayamayan kimi insanların sanal ortamlarda siber zorbalık davranışında bulunarak karşılamaya çalıştıkları söylenebilir. Nitekim sosyal medya ortamında birçok spor izleyicisinin siber zorbalık davranışı yaptığına dair örnekler bulunmaktadır. Bu örnekler sosyal medyanın özellikleri sebebi ile birçok kullanıcıya anında ulaşabilmektedir (Doğar ve Karaca, 2019, s. 59).

Siber zorbalık kulüpleri, spor organizasyonlarını ve en önemlisi sporcuları etkileyebilir. Sporda siber zorbalıkla şu şekillerde karşılaşılabilir:

* Çevrim içi ırkçılık,

* Rakip oyunculara, takımlara ve antrenörlere yönelik tehditler ve tacizler,

* Küfürlü tweetler ve ölüm tehditleri,

* Hakemlere yönelik tehditler,

* Yanlış suçlamalar, iftira ve dedikodular.

Sporun içinde ve taraftarlık kültürüne özgü güçlü grup aidiyeti ve rekabet unsurlarının spor medyası tarafından işleniş biçimleri, nefret söylemi içeren ifadelerin dolaşıma sokulmasına neden olmaktadır. Bu durumun medya kuruluşlarının dijital platformlarında yer alan kullanıcı yorumları için de geçerli olduğu söylenebilir. Medyanın kullandığı dile ve yaklaşıma alışkın olan izleyiciler bu nefret söylemlerini yadırgamayan bir tavır içerisinde olabilmektedirler. Çevrim içi platformlarda faaliyet gösteren birçok yerli ve yabancı forum, sözlük vb. oluşumlar nefret söylemi olarak kabul edilen birçok eylemi engellemeye yönelik üyelik sözleşmeleri hazırlamış durumdadır. Ancak aynı durum YouTube, Facebook, Instagram, Twitter gibi sosyal medya platformları için geçerli değildir. Bu platformlar hem çok daha fazla sayıda kullanıcı tarafindan kullanılmakta hem de denetimden uzak yapısıy- 
la nefret söyleminin üretilmesine ve yayılmasına zemin hazırlamaktadır (Akın, 2010, s. 206-216). ${ }^{1}$

Geçmişten günümüze sporun içinde nefret söylemi olarak kabul edilebilecek birçok eylem gerçekleşmiştir. Siber zorbalık ve nefret söylemi arasındaki temel fark, nefret söylemi ile bir dil, milliyet, ırk, cinsiyet nedeniyle bir grup hedef alınırken siber zorbalıkta çevrim içi platformlar aracılığıyla genellikle bireylere yönelik saldırılar gerçekleştirilmesidir. Nefret söylemi ile mücadelenin tarihi siber zorbalığa göre daha eski olduğundan, hukuksal yaptırım uygulanma ihtimali daha yüksektir. Ancak sporcular siber zorbalıklarla kendi başlarına mücadele ederken ve hukuk sistemi henüz siber zorbalık ile ilgili kesin yargılarda bulunamazken bu mücadelenin aynı şekilde başarıya ulaşma ihtimali daha azdır.

Siber zorbalığın sporcuları psikolojik ve fiziksel olarak nasıl etkilediğini yansıtmak açısından dünyadan ve ülkemizden dikkat çekici örnekler vermek çalışmanın amacına katkıda bulunacaktır. Siber zorbalık örneklerine genellikle popüler spor dallarında göz önünde olan sporcular maruz kalmaktadır. Bu bağlamda Haziran-Temmuz 2021'de düzenlenen Avrupa Futbol Şampiyonası Finali'nde İngiltere'nin İtalya'ya mağlup olmasına yol açan penaltı vuruşlarını kaçıran üç siyahi futbolcu (Jadon Sancho, Marcus Rashford, Bukayo Saka) siber zorbaların hedefi hâline gelmiştir. Sosyal medyada paylaşılan binlerce ırkçı yorumun yanı sıra Marcus Rashford'un memleketi Manchester'da yer alan grafitisi yağmalanmıştır. Saldırıların boyutu ciddileştiği için önce İngiltere Futbol Federasyonu sonrasında ise Prens William ve Başbakan Boris Johnson'dan kınama çağrıları gelmiştir. Johnson, "Bu İngiltere takımı, sosyal medyada ırkçı saldırıları değil, kahraman olarak övülmeyi hak ediyor. Bu korkunç istismarın sorumluları kendilerinden utanmalı." açıklamasını yapmıştır. Prens William ise paylaştı̆̆ tweette, "Dün geceki maçtan sonra İngiliz oyunculara yönelik ırkçı tacizden midem bulandı." diyerek oyuncuların bu iğrenç davranışa katlanmak zorunda kalmasının kesinlikle kabul edilemez olduğunu belirtmiştir. Twitter ertesi sabah, oyunculara yönelik 1.000 gönderiyi kaldırdığını ve "bir dizi hesabı kalıcı olarak askıya aldığını" açıklarken, Facebook, Instagram'dan kaç tane olduğunu belirtmeden "aşağılık yorumları" sildiğini belirtmiştir (Wall Street Journal, 2021).

\footnotetext{
${ }^{1}$ Açılımı Açık, Mert, Korkusuz olarak belirtilmiş olsa da Türkiye'de AMK adında bir spor gazetesinin 7 yıl boyunca yayınlandığını, 2019 yılında ise yayın hayatına son verdiğini belirtmek gerekir.
} 


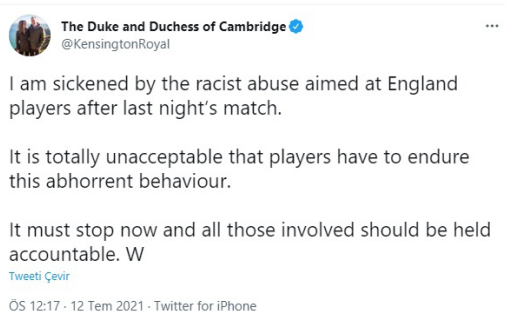

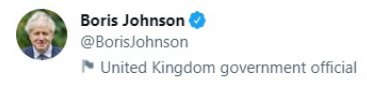

This England team deserve to be lauded as heroes, not racially abused on social media.

Those responsible for this appalling abuse should be ashamed of themselves.

Tweeti çevir

Ōö 9:02 · 12 Tem 2021 - Twitter Web App

Fotoğraf 1. Prens Williams'ın ve Başbakan Johnson'ın İngiliz Futbolcuların Maruz Kaldığı Siber Saldırılar ile İlgili Tweetleri

Henüz 20'li yaşlarının başlarında olan bu üç İngiliz futbolcunun maruz kaldıkları saldırılardan sonra yaşadıkları psikolojik sıkıntıları tahmin etmek çok da zor değildir. Son şampiyonluğunu 1966 Dünya Kupası'nda kazanan İngiltere futbol takımını o tarihten sonraki en büyük başarısına ulaştiran futbolcular kaybettikleri final maçı sonrasında maruz kaldıkları yorumlar nedeni ile psikolojik olarak olumsuz etkilenmişlerdir. Sosyal medyanın ve yeni iletişim teknolojilerinin insanları birbirlerine daha önce hiç olmadığı kadar yakınlaştırdığı, zaman ve mekân kavramlarını dönüştürdüğü bir dünyanın sunduğu olanaklar kadar, bu dönüşümün yaşattı̆̆ı sancıların da vurgulanması önemlidir.

Futbol dünyasında siber zorbalığa karşı kamuoyunda en büyük etkiyi yaratan isimlerden birisi de ünlü Fransız futbolcu Theirry Henry olmuştur. Siber zorbalıkla mücadelede gereken adımlar atılana kadar hiçbir sosyal medya uygulamasını kullanmayacağını belirtmiştir. İngiliz Teknik Direktör Gareth Soutgate, Henry'nin popüler ve saygın bir figür olarak atmış olduğu bu adımın İngiltere Milli Futbol Takımı'nda forma giyen diğer sporcuları etkilediğini belirtmiştir. Bu açıklamalar sonrasında başta Manchester United ve Sweanse kulüpleri ve futbolcuları olmak üzere birçok kulüp ve sporcu sosyal medya uygulamalarına karşı düzenlenen boykot kampanyasını yaygınlaştırmışlardır (Sky Sports, 2021).

Özellikle İngiltere'de siber zorbalık ve futbol ilişkisi konusunda oluşmaya başlayan bu farkındalık spor yayıncılarını da etkilemiştir. İngiltere'nin en ünlü spor kanallarından birisi olan Sky Sports, siber zorbalıkla mücadele konusunda yayınladığı manifestoda; skysports.com'da ve sosyal medya platformlarındaki platformlarında yayınlanan küfürlü, nefret dolu yorumları ve bu yorumları yapanları engelleyeceklerini, siber zorbalıkta bulunan hesapları sosyal medya platformlarına bildireceklerini ve gerekirse bu vakaları adli makamlara ileteceklerini belirmişlerdir (Sky Sports, 2021). Siyahi futbolcular İngiltere'de kendilerine yönelik tehditleri 
vurgulama konusunda giderek daha fazla seslerini yükseltmektedirler. Örneğin, Manchester City'de oynayan İngiliz yıldız Raheem Sterling, 2019 yılından beri sporda ırkçılığa karşı halka açık bir kampanya yürütmektedir. Ayrıca İngiltere Premier Lig organizasyonu, kulüpler ve oyuncular sosyal medya şirketlerini siber zorbalığa karşı daha güçlü adımlar atmaya teşvik etmek için 2021 Nisan ayında dört günlüğüne sosyal medya hesaplarını kapatarak boykot yapmışlardır (T24, 2021).

Bireylere güvenli bir ortam sağlayan anonim olma özelliği, internet üzerinde mesaj kaynağının kendisini gizleyebilme durumunu açıklayan bir kavramdır. Kullanıcının farklı isimler ve kimliklerle sosyal medyada yer alması kimlik yönetiminin en yaygın olarak karşılaşılan örneklerindendir. Bu şekilde kullanıcılar gerçek dünyada yapamadıkları, ifade edemedikleri, açığa vurmaktan çekindikleri her türlü durum, tutum ve fikri bilgisayar klavyesinin olanakları içerisinde ifade edebilir (Timisi, 2004, s. 96-97). Bu durum, kimi zaman demokrasiye katkı sunan bir potansiyele sahip olabilecekken kimi zamansa tam tersi, siber zorbaların kullandığı bir enstrüman olarak antidemokratik bir amaca hizmet edebilmektedir. Zira sosyal medya temsil ettiği kitlenin bütün problemli yönlerini ortaya dökebilecek bir ortamı hazırlamaktadır.

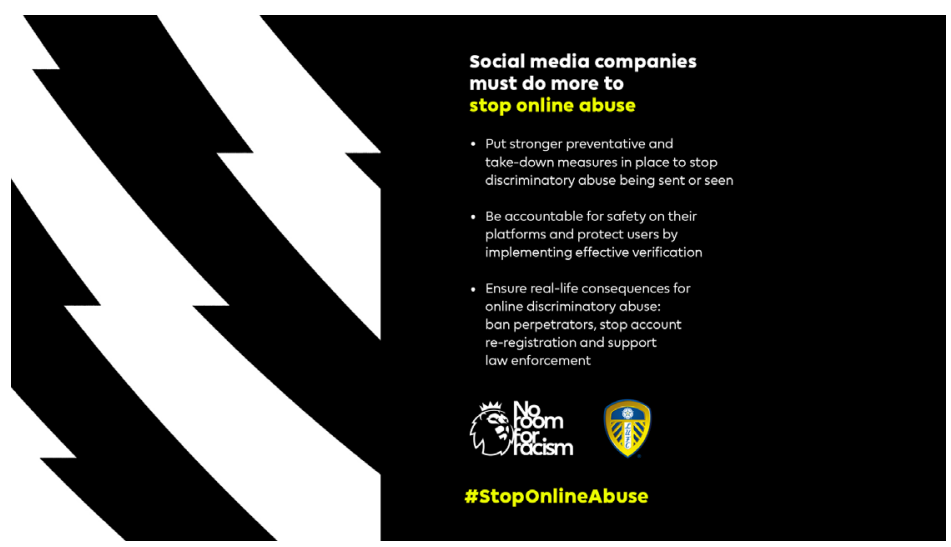

Fotoğraf 2. Premier Lig Organizasyonunun Siber Zorbalıkla Mücadele Konusunda Başlattğı Kampanya ile İlgili Görsel

Sporda siber zorbalık yalnızca ırkçılık üzerinden gerçekleşmemektedir. Sporcular cinsiyetçi ifadeler içeren siber zorbalıklarla da zaman zaman karşılaşmaktadır. Sporcular yalnızca saha içinde gösterdikleri performans ile değil, aynı zamanda kamusal alanda sergiledikleri davranışlarla da gündem olabilmekte ve siber zorbalıkla yüzleşmek durumunda kalmaktadırlar. Bunun en güncel örneklerinden birisi ülkemizde yaşanmıştır. Galatasaray ve Milli Takım'ın genç futbolcusu 
Taylan Antalyalı, 28 Haziran 2021 günü paylaşmış olduğu Instagram hikâyesinde gökkuşağı renklerinde "Powered by Pride" (Gücünü onurdan alır.) yazılı bir tişört giymesi sebebiyle siber zorbalığa maruz kalmıştır (BBC Türkçe, 2021). Antalyalı, karşı karşıya kaldığı aşağılayıcı ifadeler sebebi ile paylaştı̆ı fotoğrafi hemen kaldırmak zorunda kalmıştır. Galatasaray Kulübü ise, bir süre sessiz kaldıktan sonra Antalyalı'ya sosyal medyada destek veren taraftarların baskısı sonucu açıklama yapmıştır. Yönetim Kurulu Sözcüsü Remzi Sanver, "Galatasaray Kulübü olarak tereddütsüz olarak yanında durduğumuzu, dilerse hukuki süreçler de dâhil olmak üzere her türlü desteği vermeye hazır olduğumuzu ifade ediyoruz." ifadesini kullanarak Antalyalı'ya sahip çıkmıştır (Sözcü, 2021). Ayrıca "Taylan Antalyalı'nın sosyal medyada bu yönde verdiği mesajdan dolayı muhatap olduğu, demokratik eleştiri sınırlarının çok dışındaki ifadeleri en güçlü şekilde kınadıklarını" belirtmiştir (BBC Türkçe, 2021).

Sporu yalnızca fiziksel güç ile tanımlayan toplumsal cinsiyetin ideolojik kurumları, kadınları ve diğer cinsel yönelimlere sahip insanları spor alanında önemsizleştirmektedir. Bu bağlamda toplumsal yapıyı yansıtan, kadın-erkek arasındaki cinsiyete dayalı ayrımcılığın en fazla yapıldığı toplumsal alanların başında spor gelmektedir (Büyükafşar, 2016, s. 71). Bu durum özellikle futbol ortamının yarattı̆̆ gerilim ve rekabet ile birleştiği zaman bu tarz toplumsal olaylara ortak tepkilerin verilememesine neden olmaktadır. Galatasaray kulübünün diğer kulüplere Taylan Antalyalı'ya sahip çıkmalarına yönelik açıklama yapmaya davet etmesine rağmen hiçbir kulübün buna yanaşmaması siber zorbalığa karşı kolektif olarak tepki gösterme şansını ortadan kaldırmıştır.

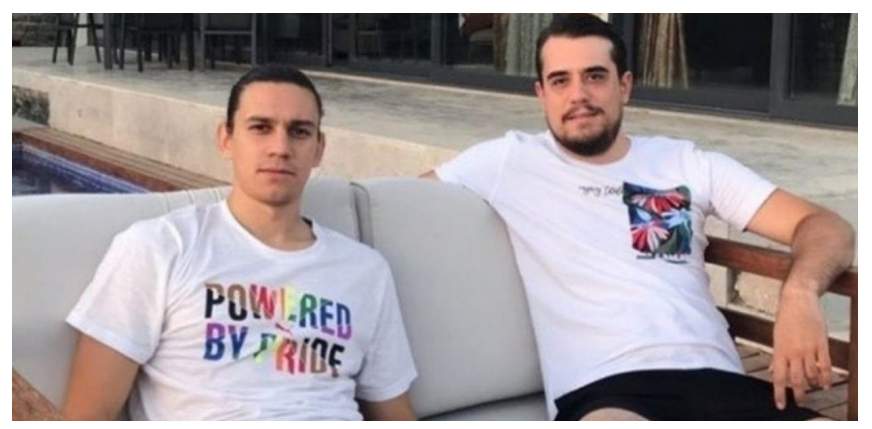

Fotoğraf 3. Galatasaraylı Futbolcu Taylan Antalyalı'nın Sosyal Medyada Tartışmalara Yol Açan Fotoğrafi

Spor alanında siber zorbalığa en fazla maruz kalanlar genellikle sporculardır. Sporcuların özellikle fiziksel görünüşleri ile ilgili karşı karşıya kaldıkları siber zorbalıklar yüzünden kimi zaman spor hayatları sonlanmakta, kimi zamansa sporcular geri 
dönülemez durumlarla karşı karşıya kalabilmektedirler. Japon güreşçi Hana Kimura, 2020 yılının Mayıs ayında henüz 22 yaşındayken fiziksel özellikleri nedeniyle kendisi hakkında yapılan yorumlar sebebi ile intihar etmiştir. Netflix'te yayınlanan Terrace House dizisinin başrol oyuncularından birisi olan Kimura, dünya çapında bir popülerliğe ulaşmış ancak bu durum onun siber zorbalığa daha fazla maruz kalmasına neden olmuştur. Siber zorbalık sebebi ile intihar eden ilk sporcu olan Kimura'nın ölümüne sebep olan yorumları yapan bir kişiye yalnızca 675 lira para cezası verilmesi de hukuki yaptırımların siber zorbalık söz konusunu olduğunda yetersiz kaldığını gözler önüne sermektedir. Adı belirtilmeyen kullanıcının sosyal medya aracılığıyla Kimura'ya, "Çok berbat bir kişiliğe sahipsin. Hayatın yaşamaya değer mi?" ve "Selam. Ne zaman öleceksin?" gibi birçok ifadenin de yer aldığı mesajlar gönderdiği bildirilmiştir. Ölümünden önceki günlerde Kimura, Twitter'da yaşadığı siber zorbalıkla mücadelesinden bahseden bazı gönderiler paylaşmıştır. Kimura'nın Instagram'daki son gönderisinde kedisi ile birlikte bir fotoğrafta, "Seni seviyorum, uzun, mutlu bir hayatın olsun. Özür dilerim." Ifadesini kullanarak içine düştüğü ruhsal bunalımın boyutunu ve yaşadığı çaresizliği tüm dünya ile paylaşmıştır (IndependentTürkçe, 2021).

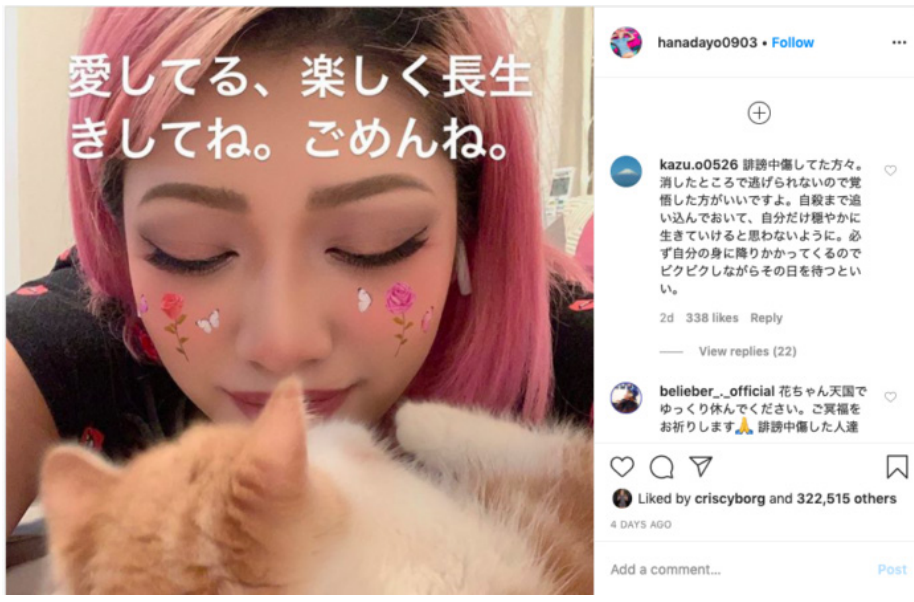

Fotoğraf 4. Maruz Kaldığı Siber Saldırılar Nedeniyle İntihar Eden Kimura'nın Son Instagram Paylaşımı

Genç yaştaki sporcuların belirli bir popülerliğe ulaştiktan sonra maruz kalabilecekleri siber zorbalık eylemlerinden etkilenmemeleri ve bu durumu tek başlarına hâlledebilmeleri mümkün değildir. Dolayısıyla tüm sporcuların ve spor organizasyonlarının gerekli adımların atılması için sosyal medya şirketlerine baskı 
yapmaları siber zorbalıkla mücadele açısından önem taşımaktadır.

Kimura'nın başına gelen olayların benzeri Türkiye'de de yaşanmıştır. Olimpik seviyede başarılı bir milli jimnastikçi olan 20 yaşındaki Tutya Yılmaz, maruz kaldığı siber zorbalıklar nedeni ile sporu bıraktığını açıklamıştır. Kendisi 16 yaşında Türkiye'yi olimpiyatlarda temsil eden en genç sporcu olarak tarihe geçmiş olmasına rağmen kendisinin fiziksel görünüşü ile ilgili aşağılayıcı yorumlar, spor yaşantısını olumsuz şekilde etkilemiştir. Paylaşmış olduğu elbiseli bir fotoğrafta vücudunun kaslı olması ile ilgili yorumlar sebebiyle özgüveninin sarsıldığını belirtmiştir. Sonrasında Twitter'dan yaptı̆̆ açıklamada, "Ben buyum ve ben kendimi bu hâlimle seviyorum. Senin 'kas yığını' dediğin şey benim 16 yıllık emeğim, gözyaşım, döktüğüm ter, harcadığım emek, kaçırdığım mezuniyetim ve yazamadığım bir dünya şey" ve "her ne kadar bu yorumları ciddiye almıyorum desem de zaman zaman insanın kalbini kırılıyor, çünkü nihayetinde ben de bir insanım..." diyerek aslında maruz kaldığı siber zorbalıkların psikolojisini etkilediğini dile getirmiştir.

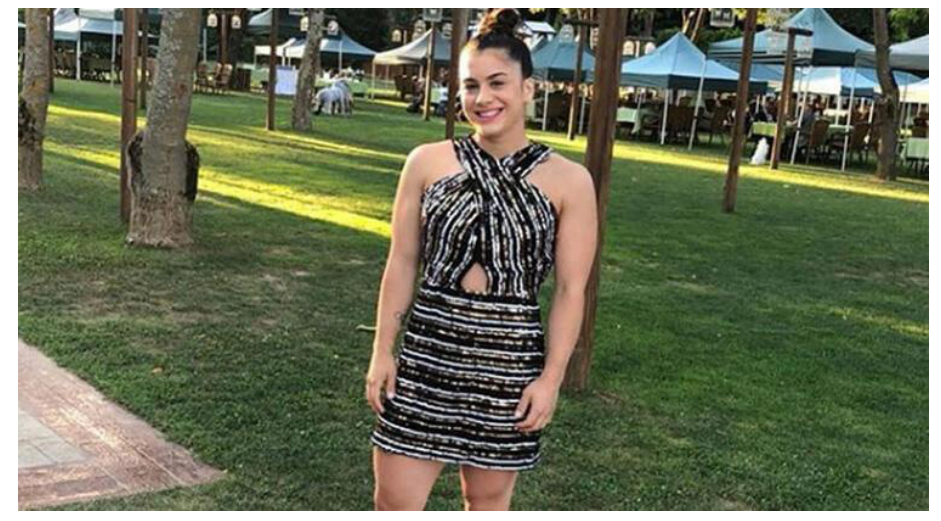

Fotoğraf 5. Milli Jimnastikçi Tutya Yılmaz'ın Siber Saldırılara Maruz Kalmasına Neden Olan Paylaşımı

Toplumsal cinsiyet diğer tüm alanlarda olduğu gibi spor alanında da en önemli faktörlerden biridir. Toplumun kimliği pozisyonlandırdığı yer, spor alanındaki yeri de belirlemede çok etkilidir. Prof. Dr. Canan Koca'nın Sporda Toplumsal Cinsiyet Eşitliğinin İzlenmesi Projesi kapsamında yapmış olduğu araştırmada 52 federasyonun başkan yardımcısı, başkan vekili ve asbaşkan pozisyonları incelendiğinde bu pozisyonda bulunan 104 kişi arasında, sadece Türkiye Beyzbol, Softbol, Korumalı Futbol ve Ragbi Federasyonu başkan vekilinin kadın olduğu tespit edilmiştir. Pozisyonda görevli olan kadınların oranı \%1'dir. 53 federasyonun genel sekreteri pozisyonunda 3 kadın görev yapmaktadır. 59 federasyonun yönetim kurulları 
başkan, başkan yardımcıları ve genel sekreter pozisyonları dâhil edilmeden incelenmiştir. Federasyonların yönetim kurullarında toplam 722 kişi görev alırken bunların \%3'ü kadın yöneticilerdir (Koca, 2018, s. 134-144).

Bu rakamlar aslında kadın sporcuların erkeklere oranla daha fazla başarıya ulaştğı voleybol, atletizm vb. birçok branşta dahi yönetici olarak yeterince yer alamadıklarını ortaya koymaktadır. Kadınların kulüplerin ve federasyonların yöneticilik veya antrenörlük pozisyonlarında daha fazla yer almaları, siber zorbalık mağdurlarının kendilerini rahatça ifade edebilecekleri bir ortamın oluşturulması ve bu saldırıların olumsuz etkilerini azaltabilmek açısından önemlidir.

Üstün ve Ekin (2021) çeşitli sosyal medya platformlarında 10.000 ve üzeri takipçi sayısına sahip görsel spor medyasında çalışan 6 kadın katılımcı ile yaptıkları araştırma sonucunda katılımcılar, ekran karşısında spor yorumlayan kadınları görmeye aşina olunmadığı için hor görüldükleri ve kendilerine güvenilmediğini ifade etmişlerdir. Katılımcıların değindiği noktalardan birisi de rakip takım taraftarlarınca sistemli bir şekilde siber zorbalığa maruz kaldıklarıdır. Katılımcıların dikkat çektiği bir başka nokta spor medyasının ataerkil bir yapıya sahip olmasından dolayı kadınların yetersiz görülmesi durumudur. Bu durumdan ötürü spor medyasındaki kadınlar kendilerini sürekli olarak ispat etmeye çalıştıklarını ve bunun fazlasıyla yorucu olduğunu belirtmişlerdir.

Türkiye'nin toplumsal yapısından, aileden, okuldan öğrenilen toplumsal cinsiyetçi yaklaşım ve spor ortamının erkek egemen yapısı düşünüldüğünde kadın sporcuların başarılı olduğu söylenebilir (Irak, 2012). Spordaki erkek egemen yapının yıkılması siber zorbalıkla mücadelenin çözümü olabilir.

\section{Amaç ve Kapsam}

Bu çalışmada sporcuların sosyal medyada maruz kaldığı siber zorbalıklardan örnekler incelenerek sporcuların hangi konularda kendilerini geliştirmeleri ve nasıl bir strateji izlemeleri gerektiği konusunda öneriler geliştirilecektir. Bu bağlamda sporcuların, kulüplerin, menajerlerin siber zorbalık konusunda farkındalıklarını tespit etmek ve çözüm önerileri geliştirmek için bir zemin oluşturulmasına katkı sağlamak çalışmanın temel amacını oluşturmaktadır. Genç yaştaki sporcuların sosyal medya ortamlarında olası bir kriz atmosferinde psikolojik olarak yıpranmamaları ve sağlık bir iletişim sürdürebilmeleri için sporcuların, kulüplerin ve menajerlerin üstlenmesi gereken sorumluluklar vurgulanacaktır.

Literatürde siber zorbalıkla ilgili çeşitli yaş gruplarından öğrenciler ile yapılan araştırmalar tespit edilmiş ve sporcu perspektifinden yapılan araştırmaların oldukça az olduğu görülmüştür. Bu bağlamda alandaki boşluğu doldurmak ve alana 
katkıda bulunmak çalışmanın temel amaçlarındandır.

Literatürde siber zorbalık alanında yapılan çalışmalar genellikle çocuklar veya genç yetişkinler hakkında yapılmış olsa da aslında sosyal medya platformlarına yeterince hâkim olmayan ve bu ortamların sosyalleşme diline yabancı kalan yetişkin kullanıcılar da siber zorbalıktan nasibini alabilmektedir. Yeni medya okuryazarlığı eğitiminin verimli şekilde verilmemesi, siber zorbalığın daha şiddetli yaşanmasına sebep olmaktadır. Dolayısıyla sosyal medya platformlarında yer alan her bireyin asgari düzeyde de olsa yeni medya okuryazarlığı konusunda kendisini yetiştirmiş olması beklenmektedir. Sporcu perspektifinden baktı̆ımızda ise yeni medya çağında sporcuların altından kalkmak zorunda oldukları bir diğer unsur da sosyal medya platformlarında kendilerine yönelik siber zorbalığa varan içeriklerdir. Sporcuların özellikle genç yaştan itibaren bu yönde bir eğitim alma zorunIuluğu artmaktadır. Özellikle ergenlik döneminde bu tür zorbalıklar sporcuların gelişimini engelleyebilmektedir. Örneğin sporcular kimi zaman müsabaka kaybettikleri ya da kamuoyu tarafindan performanslarının başarısız olarak nitelendirildiği zamanlarda sosyal medya platformlarında linç ve zorbalıkla baş başa kalabilmektedir. Bu kriz durumlarında sporcuların psikolojilerini koruyabilmeleri için sosyal medya platformlarında nasıl davranmaları gerektiği konusunda uzmanlar tarafindan bilgilendirilmeleri gerekmektedir.

\subsection{Yöntem}

Çalışmada nitel araştırmalarda sıklıkla kullanılan derinlemesine görüşme tekniği kullanılmıştır. Araştırmadaki katılımcılar, amaçlı örnekleme yöntemlerinden olan kartopu örnekleme yöntemi kullanılarak belirlenmiştir. Görüşmelerin tamamı katılımcılardan izin alınarak zoom uygulaması üzerinden kaydedilmiştir.

Siber zorbalığı sporcuların perspektifinden yorumlayabilmek amacıyla 15 sporcu ile derinlemesine görüşme gerçekleştirilmiştir. Derinlemesine görüşme yönteminin tercih edilmesinin sebebi, çalışmanın bireylerin tecrübelerine yönelik daha kapsamlı bilgiye ulaşmasını gözeterek hazırlanmış olmasıdır. Sorular önceden belirlenmiş temalar etrafinda oluşturulmuş, sıraya konulmuş ve sporculara aynı tarzda sorular sorulmuştur.

Görüşmeler pandemi sebebi ile çevrim içi olarak gerçekleştirilmiştir. Çalışmanın çevrim içi olarak gerçekleştirilmesi sebebiyle çoğu katılımcının kendilerini yeterince rahat hissetmediği ve bazı soruları cevaplamaktan kaçındıkları gözlemlenmiştir. Bu noktada yüz yüze yapılacak olan derinlemesine görüşmelerin daha etkili olabileceği ihtimali değerlendirilmiştir. Görüşmeler ortalama olarak 50-60 dakika sürmüştür. Toplanan veriler önceden belirlenen temalar çerçevesinde yorumlan- 
mış ve bu temalar iki farklı araştırmacı tarafindan oluşturulmuştur. Araştırmanın güvenirlik ve geçerliğini sağlamak adına temaların iki araştırmacı tarafindan belirlenmesi çalışmanın objektifliği açısından önemlidir.

Bu çalışmada sporculara odaklanılmasının sebebi sporcuların diğer internet kullanıcılara göre medyada daha fazla göz önünde olmaları ve medyayla bağlarının kuvvetli olmasıdır. Çalışmanın kapsamını sınırlandırmak amacıyla yalnızca sporculara odaklanılmıştır.

\section{Bulgular}

Yapılan görüşmelerden elde edilen veriler doğrultusunda belirlenen temalar aşağıdaki tabloda belirtilmiştir:

Tablo 1. Görüşmelerden Elde Edilen Temalar

\begin{tabular}{|c|l|}
\hline Tema-1 & Sporcuların İnternet ve Sosyal Medya Kullanım Alışkanlıkları \\
\hline Tema-2 & Sporcuların İnternet ve Sosyal Medya Kullanım Motivasyonları \\
\hline Tema-3 & Sporcuların Siber Zorbalığa Maruz Kalma Durumu \\
\hline Tema-4 & $\begin{array}{l}\text { Sporcuların Siber Zorbalığa Maruz Kalma Türü (İf̧a, Sözlü Taciz, Hakaret, } \\
\text { Sahte Hesap vs.) }\end{array}$ \\
\hline Tema-5 & $\begin{array}{l}\text { Sporcuların Maruz Kaldığı ya da İleride Maruz Kalacağı Olası Bir Siber } \\
\text { Zorbalığın Spor ve Sosyal Hayata Etkisi }\end{array}$ \\
\hline Tema-6 & $\begin{array}{l}\text { Sporcuların Siber Zorbalığa Maruz Kalma Durumunda Davranışları ve } \\
\text { Eylemleri }\end{array}$ \\
\hline Tema-7 & Sporcuların Siber Zorbalık Farkındalık Seviyesi \\
\hline Tema-8 & $\begin{array}{l}\text { Sporcuların Perspektifinden Kulüplerin, Federasyonların ve Antrenörlerin } \\
\text { Siber Zorbalık Farkındalık Seviyesi }\end{array}$ \\
\hline
\end{tabular}

Araştırmaya katılan sporcuların yaşları ve faaliyet gösterdikleri spor branşları Tablo 2'de belirtilmiştir.

Tablo 2. Katılımcıların Yaşları ve Branşları

\begin{tabular}{|c|c|c|}
\hline Katılımcı & Yaş & Branş \\
\hline K1 & 18 & Tekvando \\
\hline K2 & 24 & Futbol \\
\hline K3 & 18 & Futbol \\
\hline K4 & 25 & Judo \\
\hline K5 & 20 & Judo \\
\hline K6 & 22 & Tekvando \\
\hline K7 & 19 & Judo \\
\hline
\end{tabular}




\begin{tabular}{|c|c|c|}
\hline Katılımcı & Yaş & Branş \\
\hline K8 & 25 & Futbol \\
\hline K9 & 23 & Jimnastik \\
\hline K10 & 20 & Tekvando \\
\hline K11 & 20 & Judo \\
\hline K12 & 21 & Judo \\
\hline K13 & 24 & Atletizm \\
\hline K14 & 19 & Atletizm \\
\hline K15 & 21 & Futbol \\
\hline
\end{tabular}

Katılımcıların tamamı 18-25 yaş arasındadır. 3 katılımcı tekvando, 4 katılımcı futbol, 5 katılımcı judo, 1 katılımc jimnastik, 2 katılımcı ise atletizm branşında aktif ve lisanslı spor yapmaktadır.

Yapılan görüşmelerde sorulacak sorular hazırlanırken siber zorbalık ile ilgili yapılan nitel araştırmalar incelenmiş ve sorular belirlenmiştir.

Görüşmelerden elde edilen veriler temalara göre analiz edilmiş ve sınıflandırılmıştır. Katılımcıların isimleri ve bağlı bulundukları kulüpleri gizlenmiştir. Yapılan görüşmelerde temaları özetleyen alıntılar araştırmacılar tarafindan belirlenmiştir.

Tema 1. Sporcuların Internet ve Sosyal Medya Kullanım Alışkanlıkları

Yapılan derinlemesine görüşmelerden elde edilen veriler doğrultusunda katılımcıların çoğunlukla 5 saat ve üzerinde sosyal medya araçlarını kullandıkları tespit edilmiştir.

K1 "Sabah akşam antrenman oluyor. Onun dışında uyuyorum. Akşam boyu telefon elimde oluyor. 6 saat falan."

K4 "Antrenmanlar yoksa bilgisayar ya da telefona bakıyorum zaten. Günde 5-6 saati buluyor yani. Zaten pandemi yüzünden hep evdeyiz, yapacak bir şey yok."

Sporcuların günlük internet kullanım süreleri ortalama 5 saat ve üzerindedir. Bu durum sosyal medya ve internet kullanımının sporcuların sosyal hayatında önemli bir yer tuttuğunu göstermektedir. We Are Social'ın yaptığı araştırmaya göre Türkiye'de insanlar günde ortalama 7 saat 57 dakikayı internette geçirirken bunun 2 saat 57 dakikasını sosyal medya uygulamalarında geçirmektedir (We Are Social, 2021). Özellikle 2010'lu yıllarda sosyal medya platformlarının yaygınlaşmasıyla birlikte internet kullanım alışkanlıkları artmıştır. Bu noktada geniş bir kullanıcı kitlesinden söz etmek mümkündür. Sporcuların da günlük hayatlarında internet 
kullanımına ayırdıkları zaman dilimi artmış ve daha fazla kullanıcı ile etkileşime girmeye başlamışlardır.

Tema 2. Sporcuların İnternet ve Sosyal Medya Kullanım Motivasyonları

Yapılan derinlemesine görüşmelerden elde edilen veriler doğrultusunda katılımcılar genellikle eğlenmek, keyifli vakit geçirmek ve kişisel paylaşım yapmak amacıyla sosyal medya ve internet kullandıklarını belirtirken katılımcıların bir kısmı eğlenmenin yanı sıra kendi ilgi alanları hakkında araştırma yapmak, diğer sporcuların yaşantıları, antrenman teknikleri gibi bilgilere erişmek amaçlı kullandıklarını ifade etmişlerdir.

K7 "Tek bir amaçla internet kullanmıyorum. Genellikle kafa dağıtmak için videolar izliyorum. Bazen dizi izliyorum. Ayrıca dünyaca ünlü judocuların maçlarını izliyorum onlardan bir şeyler öğrenmek için."

K13 "Kendimle ilgili komik ve eğlenceli paylaşımlar yapıyorum. Tanıdıklarım da bayağı beğeniyor. Spor dışında da bana bir eğlence oluyor..."

Sporcular sosyal medya kullanımlarında öncelikle dizi, film ve videolar izlemek gibi keyifli vakit geçirme motivasyonu barındıran eylemlerde bulunmaktadırlar. Bunun yanı sıra kendi spor alanları ile ilgili bilgilere ulaşmak ve kendilerini geliştirmek için de sosyal medyayı kullanmaktadırlar.

Sporcuların birçoğu kişisel gündelik yaşamalarını, takım aidiyetlerini, aile yaşantısını sosyal medya araçları aracılığıyla paylaşmaktadır. Bu paylaşımlar sporcular ve izleyiciler arasındaki etkileşimi arttırır ve sporcuları çok daha ilgi çekici hâle getirir. Sporcuların paylaşth̆̆ içerikler taraftarların ve sponsorların algısını olumlu ya da olumsuz şekilde etkileyebilir. Toplum yapısına ya da taraftarların değer atfettikleri konulara aykırı şekilde oluşturulan içerikler, sporcuların toplumdan aldığı desteğin azalmasına ve kariyer gelişimlerinin zarar görmesi riskini ortaya çıkarabilir (Ünver ve Köse, 2020, s. 360).

\section{Tema 3. Sporcuların Siber Zorbalığa Maruz Kalma Durumu}

Yapılan derinlemesine görüşmelerden elde edilen veriler doğrultusunda yalnızca 5 katılımc siber zorbalığa maruz kalmadığını belirtirken 10 katılımcı nadiren ya da sıklıkla siber zorbalıkla karşılaştıklarını belirtmişlerdir. 2019 yılında UNICEF ve BM Genel Sekreteri Çocuklara Yönelik Şiddet Özel Temsilcisi (SRSG) tarafindan yapılan çalışma, gençlerin siber zorbalığa maruz kalma durumlarını ortaya koymaktadır. 30 ülkede her üç gençten biri çevrim içi zorbalığa maruz kalmakta, her beş çocuktan biri de siber zorbalık ve şiddet gibi nedenler yüzünden okula gidememektedir. (UNICEF, 2019). Bu çalışma siber zorbalığa maruz kalma 
durumunun yaygınlığına işaret etmektedir. Benzer şekilde sporcularla yapılan derinlemesine görüşmeler sonucu elde edilen veriler de siber zorbalığa maruz kalma oranının oldukça yüksek olduğunu göstermiştir.

K11 "Fake hesaplardan falan geliyor mesajlar öyle. Hakaret falan nadir de olsa oluyor. Ama bu paylaşımlarla alakalı biraz da. Ünlü insanların paylaşımlarına bakıyorum mesela çok fazla hakaret oluyor onlara karşı. Insanlar başarıyı kıskanabilir. Yurt dışında geziyorum, belki onlara tatil gibi geliyor. Kıskançlık olabiliyor yani."

K9 "Dans ediyorsun, şarkı söylüyorsun, sen ne biçim sporcusun? Judo mu yapıyorsun dans mı ediyorsun bu ne biçim hâller? Spor yapıyorsan adabını bil, bizim de başımızı ağrıtma.' Bana böyle şeyler söylüyorlar ama ben takmıyorum yani. Herkes bir şeyler söylüyor, sonuçta herkesi umursamıyorum."

Sosyal medyada kişisel paylaşımlar yapmak konusunda daha az çekimser olan katılımcıların siber zorbalığa daha fazla maruz kaldıkları gözlemlenmiştir. Sosyal medyada daha az aktif olan sporcular ise siber zorbalıkla bireysel olarak karşılaşmadıklarını ancak diğer sporcu arkadaşlarından bazılarının bu konuda sıkıntı yaşadıklarını belirtmişlerdir.

\section{Tema 4. Sporcuların Siber Zorbalığa Maruz Kalma Türü}

Yapılan derinlemesine görüşmelerden elde edilen veriler doğrultusunda katılımcılar ifşa, sözlü taciz, hakaret, iftira ve sahte hesap kullanımı gibi yöntemlerle siber zorbalıkla karşı karşıya kaldıklarını ifade etmişlerdir.

K9 "Beni bunlar çok rahatsı etmese de başıma gelmedi diyemem. İ̧̧te türbanlı olduğum için bu sporu yapmamam gerektiğine yönelik bir sürü hakaret dolu mesaj atanlar oldu. Yok türbanlı bir kız öyle hareket yapar mı falan filan..."

K2 "Avrupa Şampiyonası'ndan sonra haberlere çıkmıştım. Instagram'da birden takipçi sayım artt. Sonrasında tanımadığım insanlardan taciz olarak sayılabilecek mesajlar aldım ama tanımadığım için ciddiye almadım."

Sporcuların en çok sözlü taciz ve hakaret şeklinde siber zorbalığa maruz kaldıkları gözlemlenmiştir. Katılımcıların çoğunluğu ileride daha ünlü olmaları durumunda daha fazla bu tür olaylarla karşılaşma ihtimalleri olduğunu belirtmişlerdir. Ancak bazı sporcuların siber zorbalığa maruz kalmış olsa bile bunu paylaşmak konusunda çekimser kaldıkları tahmin edilmektedir. Bölükbaş ve Kırık (2020), Twitter fenomenlerinin maruz kaldıkları siber zorbalık davranışlarını inceledikleri çalışmalarında katılımcıların siber zorbalık olarak adlandırılabilecek davranışlarla genellikle gündemdeki spor ve siyaset konularına dair yaptıkları paylaşımlar sonucu 
karşılaştıklarını belirtmişlerdir. Çalışmanın dikkat çeken bir diğer sonucu da spor alanında faaliyet gösteren fenomenlerin siber zorbalık içeren davranışlara maruz kalmayı mesleklerinin doğal bir sonucu olarak görmeleridir. Bu sonuca paralel olarak katılımcılar "spor hakkında konuşmaya gerek duymama" eğiliminde olduklarını belirtmişlerdir.

Tema 5. Sporcuların Maruz Kaldığı ya da İleride Maruz Kalacağı Olası Bir Siber Zorbalığın Spor ve Sosyal Hayata Etkisi

Yapılan derinlemesine görüşmelerden elde edilen veriler doğrultusunda sporcuların siber zorbalık davranışlarının sosyal hayatlarında genellikle kızgınlık, endişe, konsantrasyon kaybı ve yalnızlaşma hissi gibi duygulara yol açtığını belirtmişlerdir.

K3 "... Şimdiden bile düşünüyorum özel hayatıma çok dikkat etmem gerektiğini. Hatta daha yeni bi mesaj attılar. Cevap vermeye çekiniyorum. Eğer biriyle konuşursam konuşmamı çarpıtıp, başkasıyla paylaşırsa diye. Başarımla anılmak varken bu tarz işlerle anılmaktan endişe duyuyorum açıkçası. Konsantrasyonumu ve sporumu etkileyebilir bu durumlar."

K8 "Beni çok etkilemez ama mesela ailem benim hakkımda yazılanları görüp üzülürse çok sinirlenirim."

K11 "Linç yememek için genellikle böyle toplumsal ya da siyasi bir şey olduğu zaman bir şey paylaşmaktan çekiniyorum. Çünkü saçma sapan şeyler yazarlarsa sinirim bozulabilir yani. Ve bazılarını tehdit bile ediyorlar tehlikeli olabiliyor bu."

15 sporcunun tümü siber zorbalık davranışlarına maruz kalmanın sosyal hayatlarını çeşitli şekilde olumsuz yönde etkileyeceğini belirtmiştir. Yine katılımcılardan 10 'u ise başarılı bir sporcunun bu tarz olumsuz durumlarla da başa çıkabilecek mental güce sahip olması gerektiğini ve kendilerinin bu güce sahip olduklarını düşündüklerini ifade etmişlerdir. Fakat bu durum sporcuların siber zorbalık seviyelerinin düşük olmasıyla da ilişkilidir. Sporcular tam anlamıyla ne ile karşı karşıya olduklarının bilincinde değillerdir.

UNICEF tarafindan hazırlanan geniş kapsamlı raporda da benzer sonuçlara ulaşılmıştır. Yayınlanan raporda, çevrim içi zorbalığın mağdurların kendi evleri dâhil her yerde saldırı altındaymış gibi hissetmelerine sebep olduğunu belirtmektedir. Siber zorbalığa uğramış olan mağdurlar bir çıkış yolu olmadığını düşünmektedirler. Bu etkilerin uzun sürebileceği ve ilgili kişiyi pek çok yönden etkileyebileceği rapordaki veriler arasında yer almaktadır. Ruhsal, duygusal ve fiziksel olarak belirtilen etkiler kızgınlık, mahcubiyet, aptal yerine konma hissi, öfke, utanç hissi ya da sevilen şeylere karşı ilgi kaybı, yorgunluk (uyuyamama), karın ağrısı, baş ağrısı 
gibi semptomlar yaşamak olarak ortaya çıkmaktadır. Komik duruma düşme ya da başkaları tarafindan rahatsı edilme endişesi de mağdurları sorunları dile getirmekten alıkoymaktadır. Bazı örneklerde ise (Japon Güreşçi Hana Kimura örneğinde olduğu gibi) siber zorbalık insanların kendi yaşamlarını sonlandırmalarına yol açmaktadır (UNICEF, 2019).

Tema 6. Sporcuların Siber Zorbalığa Maruz Kalma Durumunda Davranışları ve Eylemleri

Yapılan derinlemesine görüşmelerden elde edilen veriler doğrultusunda sporcular siber zorbalıkla karşı karşıya kaldıklarında, öncelikle bireysel mücadele (engelleme, şikâyet etme, hukuki yollara başvurma) etme yoluna giderken, tehdidin boyutuna göre sonrasında aile desteği, akran desteği ya da kulüp, antrenör ve federasyon desteğine ihtiyaç duyduklarını belirtmişlerdir.

The Cybersmile Foundation tarafindan hazırlanan ve ABD'de siber zorbalığın yaygınlığını ve duygusal etkisini araştıran ulusal raporda, 16-24 yaş arası 1,096 kişiye daha önce siber zorbalık ya da tacize uğrayıp uğramadıkları sorulmuştur. Katılımcıların \%37'si "asla" cevabını vermiş, \%22'si ise "birden fazla kez" uğradıklarını belirtmiştir. Bir sonraki soruda katılımcılara siber zorbalık veya tacizle hedef alınan başka birini gördünüz mü sorusuna ise "sayamayacakları kadar çok" cevabını vermişlerdir. Yapılan derinlemesine görüşmelerde sporcuların siber zorbalıkla ilgili sorulara başkaları söz konusu olduğunda daha rahat ve açık yanıtlar verdikleri gözlenmiştir (The Cybersmile Foundation, 2021).

Görüşme yapılan sporcular siber zorbalıkla karşılaştıklarında genellikle karşılaşılan sorunun büyüklügüne ve tekrarlama sıklığına göre farklı eylemlerde bulunabileceklerini belirtmişlerdir. Ayrıca katılımcılar karşılaşabilecekleri tehditlerin boyutunu tam olarak öngöremedikleri ve bu konuda ileride gerekli eğitimleri ve psikolojik destek almalarının önemli olabileceğini fark etmişlerdir.

K8 "Böyle bir durumla karşılaşınca cevap vermiyorum ama ileri giden bir durum olursa engellerim ya da şikâyet ederim Instagram'dan falan. Tehdit gibi bir durum olursa da hukuki olarak ne yapmam gerekiyorsa yaparım."

K12 "Değişir aslında çok önemsemezsem spamler geçerim. Çok ciddi bir olayla karşılaşmadım ama karşılaşırsam arkadaşlarımla ya da antrenörümle paylaşıp ne yapmam gerektiğini sorabilirim."

Tema 7: Sporcuların Siber Zorbalık Farkındalık Seviyesi

Yapılan derinlemesine görüşmelerden elde edilen veriler doğrultusunda katılımcılar siber zorbalık konusunda genel bir kanıya sahip olmuş olsalar bile bunun 
bilinçli bir farkındalığa işaret etmediği tespit edilmiştir. Dolayısıyla bu konuyla ilgili farkındalığın sınırlı bir seviyede kaldığı gözlemlenmiştir. Emel Baştürk Akça ve İdil Sayımer tarafindan gerçekleştirilen “Türkiye'de Temel Eğitim Gençliğinde Siber Zorbalık Konusunda Farkındalık Geliştirmek; Gençlerin 'Siber Zorbalığı' Algılayışı, Yaygınlığı ve Farkındalığa İlişkin Alan Çalışması” başlıklı projede benzer bir sonuca ulaşılmış ve ergenlerin siber zorbalığa maruz kalma oranlarının yüksek olduğu tespit edilmiştir. Siber zorbalığın ne olduğu ve buna yönelik davranışların açıklandığı odak grup görüşmelerinde ergenlerin deneyimlerinin oldukça fazla olduğu görülmüştür. Çalışmada bunun sebebi olarak öğrencilerin siber zorbalık konusundaki farkındalıklarının düşük olması gösterilmektedir (Akça ve Sayımer, 2017, s. 8).

K1 "Duydum. Sanırım internette duydum. Bir de Masumiyet dizisinde duydum. Güzel bir dizi gerçekten bu konular anlatılıyor."

K6 "Zorbalık denince anlaşılıyor zaten. Internetteki hakaretleri falan açıklayan bir kavram olduğunu düşünüyorum."

Görüşme yapılan sporcuların henüz çok fazla takipçilerinin olmaması siber zorbalık konusunda endişe seviyelerinin düşük olmasında önemli bir etkendir. Ancak ileride bu tarz olaylarla karşılaşmaları durumunda gerekli farkındalık ve bilince sahip olmadıkları görülmüştür.

Tema 8: Sporcuların Perspektifinden Kulüplerin, Federasyonların ve Antrenörlerin Siber Zorbalık Farkındalık Seviyesi

Yapılan görüşmelerde sporcuların bağlı bulundukları kulüplerin, federasyonların ya da antrenörlerin sosyal medya okuryazarlığı ve siber zorbalık konusunda herhangi bir çalışma yapmadıkları gözlemlenmiştir.

K15 "Sporculuk yaşantım boyunca bu konu hakkında bir eğitim almadım. Sadece antrenörlerimiz paylaşımlarınıza dikkat edin diye uyarıyor."

K4 "Hayır. Hiç hatırlamıyorum. Ama bence kesinlikle bir eğitim verilmeli. Çünkü internet çok fazla hayatımızın içinde ve çevremde sıkınt yaşayan sporcular görüyorum."

Sporcuların yaşamlarının önemli bir parçası olan dijital teknolojiler hakkında daha bilinçli olmaları hem saldırgan davranışların azaltılmasına hem de riskli durumlara karşı kendilerini koruyacak yetenekleri kazanmalarına yardımcı olabilecektir. 


\section{Sonuç ve Öneriler}

Siber zorbalığın sporcular perspektifinden incelendiği çalışmada bu konunun seçilmesinin sebebi sporun ve sporcuların kamuoyundaki popülerliği ve dolayısıyla toplumsal yaşamda kapladığı geniş yerdir. Araştırmaya katılan sporcuların günlük hayatlarında internet ve sosyal medyanın önemli bir yer tuttuğu tespit edilmiştir. Katılımcılar internet ve sosyal medyayı eğlence, bilgi edinme, gündemi takip etme gibi motivasyonlarla kullanmaktadır. Elde edilen veriler analiz edildiğinde, katılımcıların önemli bir kısmının yaptıkları kişisel paylaşımlar sebebiyle çevrim içi ortamlarda siber zorbalığa maruz kaldıkları tespit edilmiştir.

Katılımcılar ifşa, taciz, hakaret, tehdit, suçlama, iftira gibi eylemlerin siber zorbalık olarak adlandırıldığının bilincinde değildir. Bu durum onların konuyla ilgili farkındalık seviyelerinin düşük olduğunu göstermektedir. Katılımcılara görüşmenin sonunda siber zorbalık kavramının ne ifade ettiği detaylıca açıklanmıştır. Bu açıklamaların akabinde katılımcılar bu konuda eğitim ve destek almalarının kendileri için faydalı olacağını ifade etmişlerdir. Sporcular sosyal medyada karşılaştıkları veya uğradıkları taciz, ifşa, hakaret, iftira gibi davranışların doğal bir süreç olduğunu düşündüklerini belirtmişledir. Ancak başarılı sporcuların kariyerlerinin siber zorbalığa maruz kaldıklarında olumsuz etkilendikleriyle ilgili örnekler ve bu davranışların siber zorbalık olduğu bilgisi onlarla paylaşıldığında bunun doğal bir süreç olmadığının farkına varmışlardır.

Sporcular maruz kaldıkları siber zorbalıkların onları farklı yönlerden olumsuz etkilediğini belirtseler de (konsantrasyon kaybı, motivasyon düşüklüğü, kızgınlık, endişe, öfke), bunun kariyerlerini önemli ölçüde etkileyecek bir olay olarak görmedikleri tespit edilmiştir. Sporcuların maruz kaldığı siber zorbalık davranışları yalnızca onların performansları ile ilgili değil kimi zaman onların dini inanışları, dış görünüşleri, günlük paylaşımları, aileleri ve sosyal çevreleri ile ilgili olmuştur. Bunun yanı sıra tepki almaktan çekindikleri için sporcular toplumsal ya da siyasi bir olayla ilgili görüş ifade etmekten kaçınmaya çalıştıklarını ifade etmişlerdir. Katılımcılar genellikle siber zorbalık eylemleriyle bireysel olarak mücadele etme yolunu tercih etmişlerdir. Bunun sebebi bu tarz eylemlerin duyulması konusunda bireysel olarak hassas olmaları, ailelerinin ve çevrelerinin zarar görmesi konusunda endişelenmeleridir. Sporcuların içinde bulunduğu ve yetiştiği toplumsal ve kültürel gelenekler onların bu sorunları paylaşma konusunda kararsız kalmalarına sebep olmuştur.

Literatürde yapılan araştırmalarda sporcuların bu durumlarla yalnız başa çıkmaya çalıştikları görülmektedir. Bu durum siber zorbalığın sporcuları suskunluk sarma- 
lına soktuğunu göstermektedir. Sporcular ancak durum ciddileştikten ve psikolojik anlamda durumu kaldıramayacaklarını anladıklarında destek istemektedirler. Bu noktada hukuki olarak hak arayacaklarını ve gerek ailelerinden gerekse antrenörlerinden destek alacaklarını belirtmişlerdir.

Çalışmanın bulgularında siber zorbalık saldırılarının sporcuların kariyerinde ve sosyal hayatlarında yaygın ve kalıcı etkiler bırakabileceği gözlemlenmiştir. Buna ek olarak çevrim içi ortamların anonim olma özelliğine sahip olmasından dolayı, siber zorbalığın yoğunluğunun geleneksel zorbalıktan daha fazla olduğu söylenebilir. Siber zorbalık, sporcular açısından bireysel krizlere, kulüpler ve federasyonlar açısından ise kurumsal krizlere dönüşebilme potansiyeline sahiptir. Bu yüzden hem kulüplerin hem de federasyonların teknolojik gelişmelere ayak uydurması ve iletişim departmanlarında bu konuya özellikle dikkat etmeleri gereklidir. Siber zorbalık toplumsal bir sorundur. Toplumsal sorunlara bireylerin kişisel çabaları ile çözüm bulmak zordur; sporun tüm aktörlerinin ortak çabası ve mücadelesi daha değerli sonuçların elde edilmesini mümkün kılacaktır.

Katılımcıların çoğu ifşa, taciz, sahte hesap yoluyla yapılan tacizler, hakaret gibi davranışlara aşina olsalar da bunun siber zorbalık olarak adlandırıldığıyla ilgili bilgi sahibi olmadıkları gözlenmiştir. Aynı şekilde spor kulüplerinin, federasyonların ve antrenörlerin de bu konuya dair bir çalışma yapmadıklarının bilgisine ulaşımıştir.

Siber zorbalık ve spor ilişkisi düşünüldüğünde bu konuyla mücadele ederken sporcuların, kulüplerin ve federasyonların alabilecekleri önlemler önemli olsa da tek başına yeterli değildir. Siber zorbalıkla mücadele ederken sporcuların siber mağduriyet sorunlarının ahlaki ve yasal suç boyutlarını güçlü bir şekilde ele almalı ve bu konuda onlara destek olacak yapılar oluşturulmalıdır. Sosyal medya platformları da siber zorbalıkla mücadele konusunda daha fazla çaba göstermelidir. Örneğin siber zorbalık içeren yorumların yapay zekâ teknolojisi ile otomatik olarak filtrelenmesi ve pozitif etkileşimleri ön plana çıkarması mümkün olabilir. Zira teknoloji şirketlerinin kullanıcıları koruma sorumluluğu bulunmaktadır. Sosyal medya platformları da bu sorumluluklarının gereğini yerine getirecek adımları atmalıdır. Sosyal medya şirketlerinin spor içeriklerinden fazlaca beslendiği bilinmektedir. Dolayısıyla spor organizasyonları bu önlemlerin alınması noktasında sosyal medya şirketlerine baskı uygulayabilecek güce de sahiptir.

Yeni medya okuryazarlığı eğitimi aracılığıyla sporcuların medya içeriklerini eleştirel anlamda değerlendirebilme becerisini kazanmaları oldukça önemlidir. Yapılan görüşmelerde sporcuların özellikle kaybedilen karşılaşmalardan sonra 
sosyal medyada kendileri hakkında gördükleri yorumların motivasyonlarını önemli ölçüde etkileyebileceği tespit edilmiştir. Yeni medya teknolojileri işlevine uygun olarak kullanıldığında sporcuların performansını ve motivasyonunu arttırabilecek potansiyele sahiptir. Bu yüzden sporcuların zarar görmemeleri ve bu teknolojileri sağlıkı bir şekilde kullanabilmeleri için bilinçli birer medya okuryazarı olmaları önerilmektedir.

\section{Çıkar Çatışması Beyanı}

Makale yazarları herhangi bir çıkar çatışması olmadığını beyan etmiştir.

\section{Araştırmacıların Katkı Oranı Beyan Özeti}

Yazarlar makaleye \%55 (1. Yazar), \%45 (2. Yazar) oranında katkı sağlamış olduklarını beyan ederler.

\section{Kaynakça}

Akca, E. B., \& Sayımer, İ. (2017). Siber zorbalık kavramı, türleri ve ilişkili olduğu faktörler: Mevcut araşttrmalar üzerinden bir değerlendirme. AJIT-e: Bilişim Teknolojileri Online Dergisi, 8(30), 7-19.

Akın, A. (2010). "Çevrim içi spor ortamlarında nefret söylemi: Bir topun peşinde koşan yirmi iki adam, taraftarlar ve medya". Yeni Medyada Nefret Söylemi. İstanbul: Kalkedon.

Alp, A.F. (2020). "Siber Zorbalık ve Spor". Elif Karagün, Ozan Yılmaz (Ed.), Spor bilimlerinde güncel konular ve araştırmalar-2 (ss. 68-88). Konya: Çizgi Kitabevi Yayınları.

Bauman, S., \& Bellmore, A. (2015). "New directions in cyberbullying research".

BBC Türkçe, 2021. (https://www.bbc.com/turkce/haberler-turkiye-57643093). Erişim Tarihi: 01.07.2021

Belsey, B. (2006). Cyberbullying: An emerging threat to the always on generation. http:// www.cyberbullying.ca. (Erişim Tarihi: 06.07.2021)

Betts, L. (2016). Cyberbullying: Approaches, consequences and interventions. Palgrave Macmillan UK. https://doi.org/10.1057/978-1-137-50009-0.

Bhat, C. S. (2008). Cyber bullying: Overview and strategies for school counsellors, guidance officers, and all school personnel. Australian Journal of Guidance \& Counselling, $18,53-66$.

Bölükbaş, K., \& Kırık, A. M. (2020). Siber zorbalık bağlamında Twitter fenomenleri. Kahramanmaraş Sütçü İmam Üniversitesi Sosyal Bilimler Dergisi, 17(2), 944-966. 
Büyükafşar, M. (2016). Türk spor basınında cinsiyet ayrımcılığı: Fotomaç ve fanatik gazeteleri örneği. İnsan ve İnsan, 3(9).

Cybersmile Publish National Report exploring the prevalence and emotional impact of identity-based cyberbullying on Gen Z in the U.S. (2021).

Doğar, Y., \& Karaca, Y. (2019). An Analysis on Bullying Behaviors of the Sports Spectator Students of Faculty of Sports Sciences. Journal of Education and Training Studies, 7(11).

Englander, E. K. (2020). 25 myths about bullying and cyberbullying. John Wiley \& Sons. Journal of School Violence, 14, 1-10.

Independent Türkçe, 2021. (https://www.indyturk.com/node/338566/ya\%C5\%9Fam/i\% CC\%87ntihar-eden-netflix-y\%C4\%B1ld\%C4\%B1z\%C4\%B1-japon-g\%C3\% BCre\%C5\%9F\%C3\%A7i-hana-kimuraya-siber-zorbal\%C4\%B1k-yapan). (Erişim Tarihi: 30.06.2021)

Irak, D. (2012). Sporu Kadınlar Kurtaracak! https://www.evrensel.net/yazi/32247/ sporu-kadinlar-kurtaracak. (Erişim Tarihi: 07.07.2021)

Koca, C. (2018). Sporda toplumsal cinsiyet eşitliği haritalama ve izleme çalışması.

Pehlivan, Z., \& Konukman, F. (2004). Fair-play kavraminin geliştirilmesinde okul sporunun yeri ve önemi. Spormetre Beden Eğitimi ve Spor Bilimleri Dergisi, 2(2), 49-53.

Radicchi, E., \& Mozzachiodi, M. (2016). Social talent scouting: a new opportunity for the identification of football players? Physical Culture and Sport, 70(1), 28.

Sky Sports, 2021. (skysports.com/football/news/12016/12258352/gareth-southga te-england-boss-asks-players-to-consider-joining-thierry-henrys-social-mediaboycott). (Erişim Tarihi: 09.07.2021)

Sky Sports, 2021. (https://www.skysports.com/more-sports/news/29181/12080260/ against-online-hate-sky-sports-sets-out-series-of-measures-to-fight-online-ha te-and-abuse). (Erişim Tarihi: 08.07.2021)

Sözcü, 2021. (https://www.sozcu.com.tr/spor/futbol/galatasaraydan-taylan-antalyaliya -destek-gurur-duyuyoruz-6512670/). (Erişim Tarihi: 11.09.2021)

T24, 2021. (https://t24.com.tr/haber/euro-2020-ingiltere-de-milli-takim-futbolcularin dan-hukumete-irkcilik-elestirisi-atesi-korukleyip-tiksinmis-gibi-davranamazsiniz,965718). Erişim Tarihi: 09.09.2021.Ünver, O., \& Köse, H. (2020). Sporcuların Sosyal Medya Kullanımı. Efe Akademi Yayınları.

Üstün, N. A., \& Ekin, M. (2021). Görsel spor medyasında çalışan kadınların uğradıkları siber zorbalık hakkında görüşleri. Spor ve rekreasyon araştırmaları dergisi, 3(özel sayı 1), 15-23.

Wall Street Journal, 2021. (https://www.wsj.com/articles/england-players-face-racist-a buse-after-euros-defeat-11626102596). (Erişim Tarihi: 13.07.2021) 


\section{Ekler}

Burada belirtilen sorular görüşmenin akışına göre farklı sıralamalar almış ve sondaj sorularla birlikte çeşitlenmiştir. Yapılan görüşmelerde sorulacak olan soruları hazırlanırken siber zorbalık ile ilgili yapılan nitel araştırmalar incelenmiş ve sorular bu şekilde belirlenmiştir.

1. Hangi amaçlar doğrultusunda sosyal medya araçlarını kullanıyorsunuz? (Tanıdıkları arkadaşları ile sohbet, takip ettikleri insanların ya da sayfaların paylaşımlarını görmek, içerik paylaşmak, yeni insanlarla tanışmak vs.)

2. Ne sıklıkla sosyal medya mecralarını kullanıyorsunuz?

3. Özel hayatınıza yönelik rahatsız edici ve/veya hakaret içeren mesajlar almak, dedikodu, tanışma amaçlısrarlı mesaj, adınıza sahte hesaplar açılması gibi davranışlara maruz kaldınız mı ya da şahit oldunuz mu?

4. Siber zorbalığa maruz kaldığınızda ya da kaldıysanız tepkiniz ne olurdu ya da ne oldu? (Karşıdaki kişiden buna son vermesini istemek, engellemek, okul ya da takım arkadaşlarına söylemek, antrenörleriniz ile, menajeriniz ile ya da kulüp yöneticilerinizle paylaşma, umursamama, aile ile paylaşma, içeriği silme ya da silmesini isteme, sosyal medya platformunun şikâyet kısmına iletme, hiçbir şey yapmama, aynı biçimde misilleme yapma, polise bilgi verme, hesabı silme ya da isim değiştirme, kanıt saklama vs.)

5. Eğer bir gün ünlü bir sporcu olursanız sosyal medyada daha fazla siber zorbalığa maruz kalabileceğinizi düşünüyor musunuz?

6. Kişisel bir içeriğinizin (uygunsuz fotoğraf, cep telefonu numarası vs.) sosyal medyada paylaşıldığı ve siber zorbalığa maruz kaldığınız bir durum karşısında nasıl bir tutum sergileyeceğinizi öngörüyorsunuz?

7. Siber zorbalık kavramını daha önce duydunuz mu? Kendi cümlelerinizle ifade edebilir misiniz?

8. Sizce bir sporcu siber zorbalığa maruz kalmamak için sosyal medyada nasıl önlem alabilir?

9. Illeride sosyal medya platformlarında binlerce takipçisi olan ünlü bir sporcu olsanız sizce psikolojik olarak bu durumu kaldırmaya hazır mısınız?

10. Siber zorbalığa maruz kaldığınızda ya da kaldıysanız tepkiniz ne olurdu ya da ne oldu?

11. Okulda, bağıı bulunduğunuz spor kulübünde ya da federasyonda siber zorbalıkla alakalı bir bilgilendirme ya da eğitim aldınız mı?

12. Kulüplerin sporculara siber zorbalıkla alakalı bir eğitim vermesi gerektiğini düşünüyor musunuz?

13. Sizce sporcular siber zorbalıkla mücadele edebilmek için kulüplere, yöneticilere ya da menajerlere ihtiyaç duyuyor mu? 


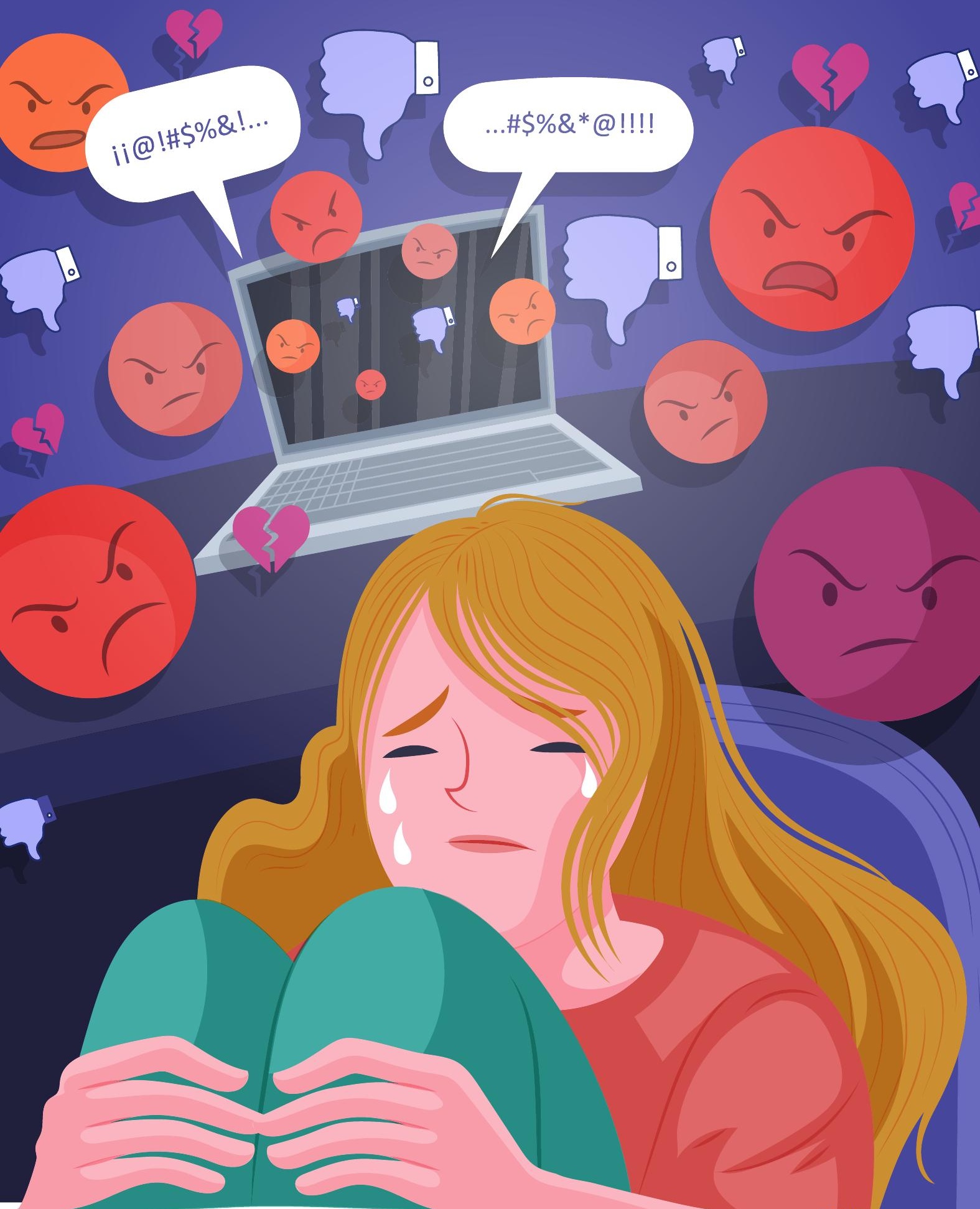

